\section{Mess with Texas}

\section{By Lev Osherovich, Senior Writer}

The public spat between the scientific board and management of the Cancer Prevention \& Research Institute of Texas is a case study in how commercial and scientific interests can clash when the two sides are not on the same page about how grants are distributed. The lesson is that academic grant reviewers need to be aware of a foundation's commercial development priorities in any proposal-vetting process.

The Cancer Prevention \& Research Institute of Texas (CPRIT) is a publicly funded agency tasked with financing basic and translational cancer research and cancer prevention initiatives in the state of Texas. ${ }^{1}$ According to its charter, the organization has a broad remit to spend $\$ 3$ billion over 10 years "to develop therapies, protocols, medical pharmaceuticals or procedures for the cure or substantial mitigation of all types of cancer."

Since 2009, CPRIT has spent about $\$ 760$ million on 427 grants to Texas academics, community health organizations and companies, the latter of which received 11 of these grants (see Table 1, "CPRIT's commercial portfolio").

According to CPRIT's rules, proposals are separated into three tracks-research, prevention and commercialization-with separate review councils that evaluate them according to distinct criteria.

Each review council selects projects to recommend for approval by CPRIT's governing board of 11 political appointees, who can in principle veto recommendations with a supermajority vote.

The Commercialization Review Councilors can informally consult their counterparts on the Scientific Review Council but have the ultimate say about which proposals to recommend for approval to CPRIT's governing board.

In May, CSO Alfred Gilman announced his intention to resign from CPRIT and publicly complained to the general media that CPRIT's management was interfering in the scientific review process. ${ }^{2}$ Gilman, emeritus professor of pharmacology at The University of Texas Southwestern Medical Center, helped build CPRIT's Scientific Review Council and its network of academic peer reviewers who evaluate research-track proposals.

At issue was a $\$ 20$ million commercialization-track grant to
"There is a natural tension between the academic and commercial world, at least in some quarters. The majority of our scientific reviewers are steeped in the NIH review process, and they're not used to a commercial due diligence process."

- Bill Gimson,

Cancer Prevention \& Research Institute of Texas the Houston-Area Translational Research Consortium (HATRC), a biotech incubator at Rice University and The University of Texas MD Anderson Cancer Center's Institute for Applied Cancer Science. Gilman said CPRIT's management fast-tracked HATRC despite the science panel's reservations about the incubator's scientific merits.

Gilman also said that CPRIT retaliated against its own scientific advisors by delaying the funding of some academic grants to UT Southwestern researchers.

In response to Gilman's concerns, MD Anderson withdrew its application for HATRC's funding.

Gilman and CPRIT's management initially agreed to work together to address his concerns. Last month, however, Gilman resigned his post, as did all 8 members of CPRIT's Scientific Review Council and 29 of about 140 peer reviewers.

\section{Out with a bang}

In an October op-ed piece in the Houston Chronicle, Gilman and former CPRIT Scientific Review Council chairman Phillip Sharp called for an

Table 1. CPRIT's commercial portfolio. The Cancer Prevention \& Research Institute of Texas (CPRIT) has issued about $\$ 760$ million in funding to academic researchers, community health organizations and 11 companies in the state of Texas. Listed below are the company grants.

\begin{tabular}{lll}
\hline Recipient & Program & Funding (\$M) \\
\hline Cell Medica Ltd. & Company relocation and recruitment & 15.6 \\
\hline Caliber Biotherapeutics LLC & Biobetter cancer mAbs & 12.8 \\
\hline Peloton Therapeutics Inc. & Company formation, recruitment and relocation & 11.0 \\
\hline Molecular Templates Inc. & Engineered Toxin Bodies (ETBs) as cancer therapeutics & 10.6 \\
\hline Mirna Therapeutics Inc. & Cancer treatment including drug discovery, development and clinical trials & 10.3 \\
\hline Kalon Biotherapeutics LLC & Formation of the Texas Cancer Therapeutics Process Development Lab & 7.9 \\
\hline Pulmotect Inc. & $\begin{array}{l}\text { Expanding the market and success rates for myeloablative cancer treatments using PUL-042, } \\
\text { an innate immune stimulant }\end{array}$ & 7.1 \\
\hline Asuragen Inc. & Mutation profiling for cancer personalized medicine using next-generation sequencing & 6.8 \\
\hline Bellicum Pharmaceuticals Inc. & Clinical development of CaspaCIDe cell therapy & 5.7 \\
\hline Apollo Endosurgery Inc. & Medical devices to treat cancerous lesions in the gastrointestinal tract & 5.0 \\
\hline Rules-Based Medicine Inc. & Cancer biology and genetics research using genomics and proteomics
\end{tabular}


investigation into what they said were conflicts of interest of CPRIT's administrators. ${ }^{3}$

Sharp is an institute professor in the Koch Institute for Integrative Cancer Research at the Massachusetts Institute of Technology.

CPRIT executive director Bill Gimson said the agency acted according to its charter.

He told SciBX that commercialization-track proposals like HATRC are evaluated according to different criteria than research-track grants to academic researchers and that weighing the commercial potential of HATRC independently of its scientific merit was in line with CPRIT's policy.

The problem with the HATRC proposal arose because "Dr. Gilman thought that it should have had a science review on the academic side of the house," said Gimson.

However, Gimson maintained that because the HATRC proposal came in on the commercialization track, the advice of the Scientific Review Board was nonbinding. The apparent unwillingness of both parties to budge from these positions led to Gilman's resignation.

Gilman declined to discuss the matter with SciBX.

\section{Texas hold 'em}

Several CPRIT scientific reviewers stated in resignation letters that CPRIT's administration had pressed for re-evaluation of proposals rejected by the scientific reviewers but championed by commercial reviewers. Such a practice created the impression of favoritism, according to the former scientific reviewers.

Gimson said re-evaluation of commercialization-track proposals in light of new data and disclosures by companies was a normal part of CPRIT's review process. He said requests by commercial reviewers for scientific reviewers to re-evaluate proposals arose because of the back-and-forth dialogue between industry applicants and CPRIT's commercialization review board that is part of CPRIT's due diligence.

"New information was sent back to the researchers for reassessment. We did that in good faith to make sure that all the peer reviewers were looking at all the same information," said Gimson.

Gimson said the vetting of commercial projects is more rigorous than that of academic projects. He thinks misunderstandings by scientific reviewers of CPRIT's commercialization-track vetting process were due in part to differences in the culture of academic peer review and business due diligence.

He said scientific reviewers expected commercialization-track grant proposals to be structured like NIH grant proposals, in which all data are disclosed and reviewed up front. In contrast, the due diligence process used by industry dealmakers involves gradual disclosure of information through dialogue.

"There is a natural tension between the academic and commercial world, at least in some quarters," said Gimson. "The majority of our scientific reviewers are steeped in the NIH review process, and they're not used to a commercial due diligence process."

As CPRIT rebuilds its scientific board in the coming year, Gimson plans to bring new reviewers up to speed on the agency's back-and-forth process with commercial applicants.

"If I could do things differently in the case of the [HATRC] incubator, we would have brought the academic and commercial reviewers together at an earlier point. This would potentially have avoided the questions raised by our CSO about whether this was a commercial or purely scientific process," he said.

Gimson said that HATRC plans to resubmit its proposal, once again on the commercialization track, later this year.

\section{California dreaming}

At least one other taxpayer-funded agency-the California Institute for Regenerative Medicine (CIRM) - sees the CPRIT saga as a cautionary tale in avoiding conflicting interests.

CIRM, which was created by a statewide bond measure in 2004, aims to distribute $\$ 3$ billion over 10 years to California academic researchers and companies to develop stem cell technologies and therapies.

"I think that whenever public funding is involved you have to be extremely sensitive to anything you do that might in any way be perceived as a conflict of interest or as playing favorites," said Jonathan Thomas, CIRM's governing board chair.

Thomas said that in CIRM's review process, grant proposals first are vetted by internal scientific staff, then evaluated by an independent panel of scientific experts from outside of California and finally approved by CIRM's Independent Citizen's Oversight Committee, a 27-member panel of industry experts, academics and patient advocates.

Unlike CPRIT, CIRM has a common track for evaluating commercial and academic proposals, and all components of the evaluation process are open to the public under California's sunshine laws, which require CIRM's committee meetings to be held in public. In evaluating commercially oriented proposals, "the emphasis is on the strength of the science," said Thomas.

Thus, he thinks the internal conflict behind CPRIT's schism is unlikely to happen at CIRM.

Last week, CIRM awarded \$10.1 million to ViaCyte Inc. for preclinical development of VC-01, a cell-based therapy for type 1 diabetes. The grant adds to the $\$ 20$ million that ViaCyte received from CIRM in 2009.

Also last week, bluebird bio Inc. received \$9.3 million from CIRM for a Phase I/II trial of LentiGlobin gene therapy for $\beta$-thalassemia.

Osherovich, L. SciBX 5(43); doi:10.1038/scibx.2012.1128

Published online Nov. 1, 2012

\section{REFERENCES}

1. Osherovich, L. SciBX 5(17); doi:10.1038/scibx.2012.432

2. Kaiser, J. Science 336, 789-790 (2012)

3. Gilman, A.G. \& Sharp, P.A. Cancer institute can regain science community's respect. Houston Chronicle (Oct. 12, 2012)

\section{COMPANIES AND INSTITUTIONS MENTIONED}

bluebird bio Inc., Cambridge, Mass.

California Institute for Regenerative Medicine, San Francisco,

Calif.

Cancer Prevention \& Research Institute of Texas, Austin, Texas Massachusetts Institute of Technology, Cambridge, Mass.

Rice University, Houston, Texas

The University of Texas MD Anderson Cancer Center, Houston, Texas

The University of Texas Southwestern Medical Center, Dallas, Texas

ViaCyte Inc., San Diego, Calif. 